\title{
STRUKTUR MATEMATIKA DALAM AL-QUR'AN (TELAAH BUKU KARYA ABDUSYSYAKIR)
}

\author{
Oleh: Nursupiamin \\ Dosen Prodi Pendidikan Matematika STAIN Palopo \\ E-mail: nursupia@yahoo.com
}

\begin{abstract}
Abstrak :
Al Qur'an merupakan mu'jizat yang diturunkan kepada Nabi Muhammad SAW sebagai kitab suci umat islam yang mengandung petunjuk dan bimbingan untuk selalu berada pada jalan yang benar. Di dalam AlQur'an, Allah SWT menyajikan begitu banyak isyarat salah satunya yang berkaitan dengan hitungan atau matematika. Hal ini menunjukkan bahwa Allah SWT Maha Kuasa dan Maha Mengetahui. Pada makalah ini, akan dipaparkan telaah buku karya Abdusysyakir yang berjudul Ada Matematika dalam Al-Quran yang secara khusus membahas tentang struktur matematika dalam Al-Qur'an.
\end{abstract}

\section{Pendahuluan}

Al Qur'an merupakan mu'jizat yang diturunkan Allah SWT kepada Nabi Muhammad SAW melalui malaikat jibril sebagai kitab suci umat islam yang mengandung petunjuk dan bimbingan untuk selalu berada pada jalan yang benar. Secara leksikal, kata Qur'an mengandung arti "bacaan" dan baru pada perkembangannya kemudian dianggap merujuk kepada arti "teks yang dibaca".

Di dalam Al-Qur'an, Allah SWT menyajikan begitu banyak isyarat salah satunya yang berkaitan dengan hitungan atau matematika. Isyarat-isyarat matematika dalam Al Qur'an sebenarnya jauh lebih banyak dari beberapa buku yang membahas tentang Matematika dalam Al-Qur'an. Salah satunya dalam buku karya Abdusysyakir yang berjudul "Ada Matematika dalam Al-Quran ". Ketertarikan mengkaji buku karya Abdusysyakir dikarenakan bentuk buku yang mudah dibawah kemana-mana seperti halnya buku saku serta ketertarikan juga secara sepintas pada isi buku yang memaparkan matematika dalam AlQur'an secara terperinci dan disertai pembuktian dari struktur-struktur yang dibentuk oleh penulis buku.

Berbicara tentang pengkajian lebih dalam tentang AlQur'an, pada dasarnya Allah SWT memerintahkan kepada kaum Nabi Muhammad SAW untuk berfikir, menganalisa, memahami ilmu pengetahuan, memahami fenomena yang terjadi di muka bumi, dan mengadakan penelitian yang 
berkaitan dengan alam semesta umumnya dan kehidupan sehari-hari khususnya. Kesemuanya sangat jelas tersebut dalam ayat-ayat Al-Qur'an. Kesempurnaan Al-Qur'an juga diakui oleh Edward Gibbon, seorang pakar Barat yang mengatakan bahwa "Al-Qur'an adalah sebuah kitab agama, yang membahas tentang masalah-masalah kemajuan, kenegaraan, perniagaan, peradilan, dan undang-undang kemiliteran dalam Islam. Isi Al-Qur'an sangat lengkap, mulai dari urusan ibadah, ketauhidan, sampai soal pekerjaan sehari-hari, mulai dari masalah rohani sampai hal-hal jasmani, mulai dari pembicaraan tentang hak-hak dan kewajiban segolongan umat sampai kepada pembicaraan tentang akhlak dan perangai serta hukum siksa di dunia."

Selain masalah umum dalam kehidupan, Al-Qur'an membahas matematika lebih khusus tentang perkalian dan perhitungan bilangan dalam berbagai peristiwa dan berbagai konteks. Salah satunya yang berkaitan dengan kegiatan menghitung dimana kegiatan ini tentunya tidak terlepas dari "ukuran" yang secara jelas tersebut dalam surat AlQamar/54 : 49 berikut :

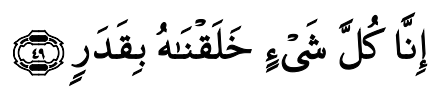

Terjemahnya : "Sesungguhnya Kami menciptakan segala sesuatu menurut ukuran"

dan surat Al Furqaan/25 : 2 sebagai berikut :

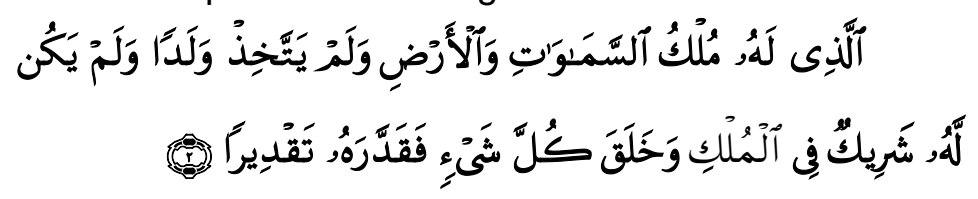

Terjemahnya : "yang kepunyaan-Nya-lah kerajaan langit dan bumi, dan Dia tidak mempunyai anak, dan tidak ada sekutu bagiNya dalam kekuasaan(Nya), dan Dia telah menciptakan segala sesuatu, dan Dia menetapkan ukuranukurannya dengan serapi-rapinya."

Matematika Islam merupakan matematika yang menjadikan Al-Qur'an dan Sunnah Nabi sebagai Postulat. Oleh karena itu, di dalam Matematika Islam tidak perlu membuktikan suatu data yang datang dari Allah SWT dan rasul-Nya sekalipun nanti dalam perjalanannya Matematika Islam seolah membuktikan kebenaran sunnah-sunnah Nabi. 
71 | al-Khwarizmi, Volume II, Edisi 2, Oktober 2014, Hal. 69 - 84

Berikut beberapa hasil pengembangan konsep Matematika yang berkaitan dengan Al-Qur'an, yaitu :

a. Rahasia angka diantaranya angka 7 dan 19 yang banyak diungkapkan baik peneliti-peneliti muslim maupun non-muslim.

b. Representasi digraph untuk nomor surat dan banyak ayat, yang menunjukkan setiap Al-Qur'an mempunyai korelasi yang menarik antar surat yang satu dengan surat yang lain. Untuk mengetahui arti atau makna dari sebuah angka, maka dikorelasikan dengan variable Al-Qur'an. Tetapi ada juga surat yang tidak berkorelasi, contohnya adalah surat Al-Baqarah. Di dalam surat Al-Baqarah dijelaskan tentang beberapa hokum yang tidak dijelaskan dalam surat lain, misalnya hokum tauhid. Sehingga surat AlBaqarah disebut Fusthaatul-Qur'an (puncak Al-Qur'an).

c. Hasil penelitian Prof. Bassam Jarrar dari Noon Centre, Amerika Serikat yang menunjukkan bahwa Al-Quran disusun berpasangan artinya terdapat 57 surat homogen (dalam hal ini nomor surat dan jumlah ayat genap atau nomor surat dan jumlah ayat ganjil) dan 57 surat heterogen (dalam hal ini nomor surat genap dan jumlah ayat ganjil atau sebaliknya).

Contoh keterkaitan lain matematika dalam Al-Qur'an adalah konsep ortogonalitas, dimana orthogonal mengandung arti tegak lurus. Keterkaitan konsep ini dengan Al-Qur'an salah satunya terletak pada konsep "hablumminallah hablumminannas" yang bermakna hubungan manusia dengan Allah swt (hablumminallah) dan hubungan manusia dengan manusia yang lain (hablumminannas). Berdasarkan sudut pandang matematika, konsep ortogonalitas diartikan dua vector dikatakan orthogonal jika hasil kali dalam kedua vector tersebut sama dengan nol. Secara geometri konsep orthogonal khususnya pada dimensi-2 digambarkan melalui dua vector yang saling tegak lurus. Seperti yang terlihat pada gambar berikut :

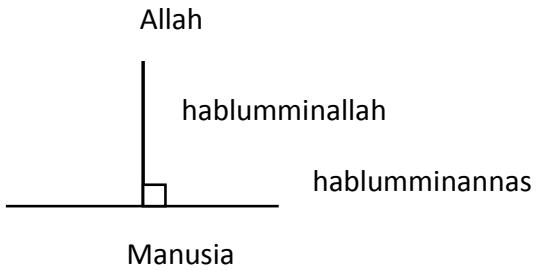

Gambar : Contoh Konsep Ortogonal dalam Al-Qur'an 
Berdasarkan gambar di atas, garis lurus secara horizontal menunjukkan kedudukan manusia di hadapan Allah swt sama, sehingga dalam menjalani kehidupan di dunia perlu menjalin hubungan yang harmonis diantara sesama manusia. Sedangkan garis lurus secara secara vertical ke atas menunjukkan tujuan hidup dari manusia di muka bumi ini tidak lain adalah beribadah kepada Allah SWT. Konsep ortogonalitas yang berkaitan dengan permasalahan ini menunjukkan ketegaklurusan garis horizontal dan vertical menjelaskan bahwa manusia seharusnya selalu menjaga hubungan silaturrahmi dengan sesama umat manusia dan juga berpegang teguh kepada Allah SWT. Konsep ini tidak terbukti salah satunya untuk orang-orang yang menyekutukan Allah swt dalam hal ini non muslim.

\section{Telaah Buku Abdusysyakir "Ada Matematika dalam Al-Qur'an"}

Buku Abdusysyakir membahas tentang melihat struktur matematika bilangan 19 dalam Al-Qur'an, mengembangkan konsep dasar matematika dari Al-Qur'an, dan memahami AlQur'an dengan Matematika. Berikut akan dipaparkan beberapa hasil telaah buku tersebut yang tentunya juga memiliki kekurangan. Akan tetapi, diharapkan dapat memberikan kontribusi bagi pengkajian matematika dalam Al-Qur'an lebih lanjut. Dalam pembahasan berikut Abdusysyakir menggunakan istilah "struktur" dalam menyajikan penemuan baik berupa penemuan pribadi maupun penemuan orang lain. Sedangkan penulis lebih pada penggunaan istilah "teorema dan akibat".

1. Melihat struktur matematika bilangan 19 dalam Al-Qur'an

Berikut dipaparkan beberapa struktur matematika atau hal-hal yang dapat ditunjukkan secara matematika, yaitu :

Bilangan 19 dalam Basmalah

\begin{tabular}{|c|}
\hline Teorema 1 / Struktur 1 \\
\hline Banyaknya huruf hijaiyah pada basmalah adalah 19 huruf \\
\hline
\end{tabular}

Bukti : Bacaan Basmalah terdiri dari 19 huruf yang tersusun atas 4 kata yaitu "Bism"(3 huruf), "Allah" (4 huruf), "ar-Rahmaan"( 6 huruf), dan "ar-Rahiim" (6 huruf).

Akibat 1 / Struktur 2, 3, 5, 6, 7

Dalam ayat Al-Qur'an, 4 kata yang menyusun bacaan basmalah disebut sebanyak kelipatan 19 . 
73 | al-Khwarizmi, Volume II, Edisi 2, Oktober 2014, Hal. 69 - 84

Bukti : Kata "ism" disebut sebanyak 19 kali $(19=1 \times 19)$ yaitu pada Q.S 5:4, 6:118, 6:119, 6:121, 6:138, 22:28, 22:34, 22,36, 22:40, 49:11, 55:78, 56:74, 56:96, 69:52, 73:8, 76:25, 87:1, 87:15, dan 96:1.

Kata "Allah" disebut sebanyak 2698kali $(2698=142 \times 19)$. Kata "ar-Rahmaan" disebut sebanyak 57kali $(57=3 \times 19)$ dan Kata "ar-Rahiim" disebut sebanyak 114kali $(114=6 \times 19)$

\begin{tabular}{|c|}
\hline Teorema $2 /$ Struktur 9 \\
\hline Banyaknya bacaan basmalah dalam Al-Qur'an ada 114 \\
\hline
\end{tabular}

Bukti : Bacaan Basmalah pada permulaan surah ada 113 (1 surah yang tidak dimulai dengan basmalah adalah surah ke 9 yaitu At Taubah) dan terdapat pada 1 surah yang terdapat bacaan basmalah pada pertengahan yaitu pada surah An Naml (27): 30.

\section{Akibat 1 / Struktur 10}

Diketahui pada surah At Taubah tidak dimulai dengan basmalah dan pada An Naml terdapat dua basmalah yaitu pada awal surah dan pada ayat 30. Jika diperhatikan dimulai surah At Taubah sampai dengan An Naml maka terdapat 19 surah.

Bukti:

\begin{tabular}{|c|c|c|c|c|c|}
\hline No & $\begin{array}{c}\text { Nomor } \\
\text { Surah }\end{array}$ & $\begin{array}{c}\text { Nama } \\
\text { Surah }\end{array}$ & No & $\begin{array}{c}\text { Nomor } \\
\text { Surah }\end{array}$ & Nama Surah \\
\hline 1 & 9 & At Taubah & 11 & 19 & Maryam \\
\hline 2 & 10 & Yunus & 12 & 20 & Thaha \\
\hline 3 & 11 & Hud & 13 & 21 & Al Anbiya' \\
\hline 4 & 12 & Yusuf & 14 & 22 & Al Hajj \\
\hline 5 & 13 & Ar Rad & 15 & 23 & Al Mu'minun \\
\hline 6 & 14 & Ibrahim & 16 & 24 & An Nur \\
\hline 7 & 15 & Al Hijr & 17 & 25 & Al Furqan \\
\hline 8 & 16 & An Nahl & 18 & 26 & Asy Syu'ara \\
\hline 9 & 17 & Al Isra' & 19 & 27 & An Naml \\
\hline 10 & 18 & Al Kahfi & & \multicolumn{3}{|c}{} \\
\hline
\end{tabular}

Oleh karena jumlah surahnya 19 maka disebut "Transformasi 19" atau "Transformasi Basmalah". Hal ini dikarenakan adanya "pergeseran basmalah" di antara surah yang berjumlah 19, sebagaimana yang tertulis dalam Q.S. An-Nahl/16 : 101 dan Q.S. Hud/11 : 13.

\section{Akibat 2 / Struktur 12}

Pada surah An Naml(surah ke-27) selain pada awal surah, bacaan basmalah terdapat pada ayat ke-30. Jumlahan 
nomor surah dan nomor ayatnya merupakan kelipatan 19 .

Bukti: $27+30=57=3 \times 19$

Teorema 3 / Struktur 14

Penyusunan angka dari jumlah kata, huruf, dan nilai numerik dari basmallah merupakan kelipatan 19

Bukti :

\begin{tabular}{|c|c|c|c|c|}
\hline No & Kata & $\begin{array}{c}\text { Banyaknya } \\
\text { Huruf }\end{array}$ & Nilai Numerik & $\begin{array}{c}\text { Total Nilai } \\
\text { Numerik }\end{array}$ \\
\hline 1 & Bism & 3 & $2,60,40$ & 102 \\
\hline 2 & Allah & 4 & $1,30,30,5$ & 66 \\
\hline 3 & ar-Rahman & 6 & $1,30,200,8,40,50$ & 329 \\
\hline 4 & ar-Rahiim & 6 & $1,30,200,8,10,40$ & 289 \\
\hline \multicolumn{2}{r|}{ Total } & 19 & & 786 \\
\hline
\end{tabular}

Susunan angka dari jumlah kata, huruf, dan nilai numerik dari basmallah yaitu 419786, dimana $419786=19 x$ 22094

\section{Teorema 4 / Struktur 16}

Barisan nomor kata dan banyaknya huruf dari masingmasing kata yang membentuk bacaan basmalah merupakan kelipatan 19

Bukti :

\begin{tabular}{|c|c|c|}
\hline No & Kata & Banyaknya Huruf \\
\hline & Bism & 3 \\
\hline & Allah & 4 \\
\hline & ar-Rahman & 6 \\
\hline & ar-Rahiim & 6 \\
\hline & Total & 19 \\
\hline
\end{tabular}

Barisan nomor kata dan banyaknya huruf dari masingmasing kata yang membentuk bacaan basmalah yaitu 13243646, dimana $13243646=19 \times 697034$

Penulis tidak mengkaji lebih dalam struktur 4, 8, 11, dan 13 dikarenakan terdapat kekeliruan dalam penulisan atau sebab dari pernyataan dari masing-masing struktur. Contohnya, pada struktur 4 ditulis kata "bismillah" dalam AlQur'an disebut sebanyak 3 kali. Akan tetapi, diketahui sesuai struktur 9 banyaknya bacaan basmalah ada 114 kali dalam Al-Qur'an. Pada struktur 8 ditulis jika pengali pada struktur 3 sampai 5 dijumlahkan maka merupakan kelipatan 19. Akan tetapi, diketahui pengali dari struktur 3 adalah 2 , pengali dari struktur 4 adalah 6 , dan pengali dari struktur 5 adalah 142. Sehingga jika ketiga pengali tersebut 
dijumlahkan tidak menghasilkan kelipatan 19. Sedangkan pada struktur 11 dan 13 hanya berupa kesalahan pengetikan dimana seharusnya pada struktur 11 mengacu pada struktur 10 bukan struktur 3 dan seharusnya pada struktur 13 tertulis An-Naml bukan at-Taubah.

Pada struktur 15, 17 dan seterusnya, penulis menganggap sebagai pengembangan atau akibat lebih lanjut dari struktur 14 dan struktur 16. Berdasarkan sifat-sifat atau stuktur matematika angka 19 di atas membuktikan bahwa Al-Qur'an diturunkan tidak hanya untuk bangsa Arab, tetapi untuk seluruh umat manusia di dunia. Misalnya untuk menghitung huruf pada ayat pertama dalam Al-Qur'an dan memastikan bahwa jumlahnya merupakan kelipatan 19, kita tidak perlu tahu bahasa Arab dulu.

Dalam Surah Berinisial

\begin{tabular}{|c|}
\hline Teorema 1/Struktur 1 \\
\hline Jumlah dari banyaknya huruf hijaiyah yang menjadi inisial \\
surah, banyaknya macam inisial surah, dan jumlah surah \\
yang mengandung surah berinisial merupakan kelipatan 19
\end{tabular}

Bukti :

\begin{tabular}{|c|c|c|c|}
\hline No & $\begin{array}{c}\text { Nomor } \\
\text { Surah }\end{array}$ & $\begin{array}{c}\text { Nama } \\
\text { Surah }\end{array}$ & Huruf Inisial \\
\hline 1 & 2 & Al Baqarah & Alif, Lam, Mim \\
\hline 2 & 3 & Ali Imran & Alif, Lam, Mim \\
\hline 3 & 7 & Al A'raf & Alif, Lam, Mim, Shad \\
\hline 4 & 10 & Yunus & Alif, Lam, Ra' \\
\hline 5 & 11 & Hud & Alif, Lam, Ra' \\
\hline 6 & 12 & Yusuf & Alif, Lam, Ra' \\
\hline 7 & 13 & Ar Rad & Alif, Lam, Mim, Ra' \\
\hline 8 & 14 & Ibrahim & Alif, Lam, Ra' \\
\hline 9 & 15 & Al Hijr & Alif, Lam, Ra' \\
\hline 10 & 19 & Maryam & Kaf, Hha, Ya', 'Ain, Shad \\
\hline 11 & 20 & Thaha & Tha', Hha \\
\hline 12 & 26 & Asy Syu'ara & Tha', Sin, Mim \\
\hline 13 & 27 & An Naml & Tha', Sin \\
\hline 14 & 28 & Al Qashash & Tha', Sin, Mim \\
\hline 15 & 29 & Al Ankabut & Alif, Lam, Mim \\
\hline 16 & 30 & Ar Rum & Alif, Lam, Mim \\
\hline 17 & 31 & Luqman & Alif, Lam, Mim \\
\hline 18 & 32 & As Sajadah & Alif, Lam, Mim \\
\hline 19 & 36 & Yasin & Ya', Sin \\
\hline
\end{tabular}


Struktur Matematika dalam Al-Quran ...| 76

\begin{tabular}{|l|c|c|c|}
\hline 20 & 38 & Shad & Shad \\
\hline 21 & 40 & Gafir & Ha', Mim \\
\hline 22 & 41 & Fushshilat & Ha', Mim \\
\hline 23 & 42 & Asy Syura & Ha', Mim, 'Ain, Sin, Qaf \\
\hline 24 & 43 & Az Zukhruf & Ha', Mim \\
\hline 25 & 44 & Ad Dukhan & Ha', Mim \\
\hline 26 & 45 & Al Jasiyah & Ha', Mim \\
\hline 27 & 46 & Al Ahqaf & Ha', Mim \\
\hline 28 & 50 & Qaf & Qaf \\
\hline 29 & 68 & Al Qalam & Nun \\
\hline
\end{tabular}

Banyaknya huruf hijaiyah yang menjadi inisial surah= 14. Banyak macam inisial surah $=14$. Jumlah surah yang mengandung surah berinisial=29. Maka $14+14+29=57=3 \times 19$ Teorema 2 / Struktur 3

Terdapat 38 surah tidak berinisial antara surah berinisial pertama (Al Baqarah) dan surah berinisial terakhir (Al Qalam) juga merupakan kelipatan 19

Bukti : Banyaknya surah dalam Al-Qur'an antara surah Al Baqarah (2) dan surah Al Qalam (68) = 65 surah. Banyaknya surah yang berinisial antara surah Al Baqarah (2) dan surah AI Qalam (68) = 27 surah. Maka Banyaknya surah yang tidak berinisial antara surah Al Baqarah (2) dan surah Al Qalam (68) $=38$ surah $=2 \times 19$

\section{Teorema 3 / Struktur 4}

Terdapat 19 himpunan berselang seling antara surah berinisial dan tidak berinisial antara surah berinisial pertama (Al Baqarah) dan surah berinisial terakhir (AI Qalam)

Bukti :

\begin{tabular}{|c|c|c|c|c|c|}
\hline Himpunan & $\begin{array}{c}\text { Nomor } \\
\text { Surah }\end{array}$ & $\begin{array}{c}\text { Keterangan } \\
\text { Surah }\end{array}$ & Himpunan & $\begin{array}{c}\text { Nomor } \\
\text { Surah }\end{array}$ & Keterangan Surah \\
\hline 1 & $2-3$ & Berinisial & 11 & 36 & Berinisial \\
\hline 2 & $4-6$ & Tidak Berinisial & 12 & 37 & Tidak Berinisial \\
\hline 3 & 7 & Berinisial & 13 & 38 & Berinisial \\
\hline 4 & $8-9$ & Tidak Berinisial & 14 & 39 & Tidak Berinisial \\
\hline 5 & $10-15$ & Berinisial & 15 & $40-46$ & Berinisial \\
\hline 6 & $16-18$ & Tidak Berinisial & 16 & $47-49$ & Tidak Berinisial \\
\hline 7 & $19-20$ & Berinisial & 17 & 50 & Berinisial \\
\hline 8 & $21-25$ & Tidak Berinisial & 18 & $51-67$ & Tidak Berinisial \\
\hline
\end{tabular}


77 | al-Khwarizmi, Volume II, Edisi 2, Oktober 2014, Hal. 69 - 84

\begin{tabular}{|c|c|c|c|c|c|}
\hline 9 & $26-32$ & Berinisial & 19 & 68 & Berinisial \\
\hline 10 & $33-35$ & Tidak Berinisial & & & \\
\hline
\end{tabular}

Penulis tidak mengkaji lebih dalam struktur 2 dikarenakan terdapat kekeliruan dalam pengetikan dimana pada struktur 2 seharusnya ditulis terdapat 10 surah berinisial yang inisialnya menjadi ayat bergabung bukan ayat tersendiri. Sedangkan pada struktur 5 dan seterusnya penulis belum melakukan telaah lebih mendalam.

Dalam Penyebutan Bilangan

\begin{tabular}{|c|c|c|c|c|c|c|}
\hline \multicolumn{4}{|c|}{$\begin{array}{l}\text { Bilangan Asli dalam Al- } \\
\text { Qur'an }\end{array}$} & \multicolumn{3}{|c|}{$\begin{array}{l}\text { Bilangan Pecahan dalam } \\
\text { Al-Qur'an }\end{array}$} \\
\hline No & Bilangan & No & Bilangan & No & Bilangan & $\begin{array}{c}\text { Banyak } \\
\text { Penyebutan }\end{array}$ \\
\hline 1 & 1 & 16 & 40 & \multirow[t]{2}{*}{1} & \multirow[t]{2}{*}{$2 / 3$} & \multirow[t]{2}{*}{3} \\
\hline 2 & 2 & 17 & 50 & & & \\
\hline 3 & 3 & 18 & 60 & \multirow[t]{2}{*}{1} & \multirow[t]{2}{*}{$1 / 2$} & \multirow[t]{2}{*}{5} \\
\hline 4 & 4 & 19 & 70 & & & \\
\hline 5 & 5 & 20 & 80 & \multirow[t]{2}{*}{3} & \multirow[t]{2}{*}{$1 / 3$} & \multirow[t]{2}{*}{3} \\
\hline 6 & 6 & 21 & 99 & & & \\
\hline 7 & 7 & 22 & 100 & \multirow[t]{2}{*}{4} & \multirow[t]{2}{*}{$1 / 4$} & \multirow[t]{2}{*}{2} \\
\hline 8 & 8 & 23 & 200 & & & \\
\hline 9 & 9 & 24 & 300 & \multirow[t]{2}{*}{5} & \multirow[t]{2}{*}{$1 / 5$} & \multirow[t]{2}{*}{1} \\
\hline 10 & 10 & 25 & 1000 & & & \\
\hline 11 & 11 & 26 & 2000 & \multirow[t]{2}{*}{6} & \multirow[t]{2}{*}{$1 / 6$} & \multirow[t]{2}{*}{3} \\
\hline 12 & 12 & 27 & 3000 & & & \\
\hline 13 & 19 & 28 & 5000 & \multirow[t]{2}{*}{7} & \multirow[t]{2}{*}{$1 / 8$} & \multirow[t]{2}{*}{1} \\
\hline 14 & 20 & 29 & 50000 & & & \\
\hline 15 & 30 & 30 & 100000 & 8 & $1 / 10$ & 1 \\
\hline$\Sigma$ & 147 & $\Sigma$ & & 1619 & & \\
\hline \multicolumn{4}{|c|}{ Total $=147+161999=162146$} & \multicolumn{3}{|c|}{ Total } \\
\hline
\end{tabular}

Teorema 1 / Struktur 1

Terdapat 38 bilangan berbeda yang disebutkan dalam Al Qur'an

Bukti : Dalam Al-Qur'an terdapat 30 bilangan asli dan 8 bilangan pecahan

Teorema 2 / Struktur 2

Jumlah 30 bilangan asli berbeda dalam Al Qur'an merupakan kelipatan 19 
Bukti : Berdasarkan tabel, total jumlah 30 bilangan asli dalam Al-Qur'an = $162146=19 \times 8534$

Teorema 3 / Struktur 3

Banyaknya penyebutan kedelapan bilangan pecahan dalam Al Qur'an sama dengan 19

Bukti : Berdasarkan tabel, total penyebutan 8 bilangan pecahan $=19$

\begin{tabular}{l} 
Teorema 4/Struktur 6 \\
\hline Jumlah dari penyebut dari bilangan pecahan yang \\
tersebut dalam Al Qur'an merupakan kelipatan 19 dan \\
sama dengan banyaknya bilangan berbeda dalam Al- \\
Qur'an
\end{tabular}

Bukti : Berdasarkan tabel, penyebut dari bilangan pecahan yang tersebut dalam Al-qur'an adalah 2, 3, 4, 5, 6, 8,10 . Dimana $2+3+4+5+6+8+10=38=2 \times 19$.

Selain itu 38 menunjukkan banyaknya bilangan berbeda dalam Al-Qur'an dimana bilangan asli sebanyak 30 dan bilangan pecahan sebanyak 8 .

Penulis tidak mengkaji lebih dalam struktur 4 dan 5 dikarenakan penulis belum melakukan telaah lebih mendalam.

Dalam Shalat dan Dzikir

\section{Teorema 1 / Struktur 2 (Shalat)}

Diketahui rakaat shalat wajib adalah $2,4,4,3$, dan 4 dan KPK dari 2, 4, 4, 3, dan 4 adalah 12. Jumlahan hasil bagi KPK dengan jumlah rakaat shalat 5 waktu merupakan kelipatan 19.

Bukti : Diketahui rakaat shalat wajib adalah 2, 4, 4, 3, dan 4 dan KPK dari 2, 4, 4, 3, dan 4 adalah 12. Maka jumlahan hasil bagi KPK dengan jumlah rakaat shalat 5 waktu $=(12: 2)+(12: 4)+(12: 4)+(12: 3)+(12: 4)=6+3+3+4+3=19$

Penulis tidak mengkaji lebih dalam struktur 1 dikarenakan pada struktur 1 bisa terdapat dua macam persepsi penentuan awal hari dari waktu subuh sampai waktu isya atau penentuan awal hari dari waktu magrib sampai waktu ashar. Kedua pandangan ini tentunya akan berimplikasi tentang pengkajian lebih dalam tentang shalat wustha dan pada keutamaan waktu subuh atau waktu ashar.

Teorema 2 / Struktur 1 dan 2(Dzikir)

Jumlahan digit bilangan dari bacaan dzikir yaitu Subhanallah (33x), Alhamdulillah (33 x), Allahu Akbar (33x), dan melengkapinya dengan 100 dengan La ilaha illallah 
sama dengan 19

Bukti : Bacaan dzikir yaitu Subhanallah (33x), Alhamdulillah (33 x), Allahu Akbar (33x), dan melengkapinya dengan 100 dengan La ilaha illallah ada dua versi, yaitu :

Versi 1 : Subhanallah (33x), Alhamdulillah (33 x), Allahu Akbar (33x), dan melengkapinya dengan La ilaha illallah menjadi 100 , sehingga Jumlahan digit bilangan $=3+3+3+$ $3+3+3+1=19$

Versi 1 : Subhanallah (33x), Alhamdulillah (33 $x)$, Allahu Akbar (33x), dan melengkapinya dengan $100 \times$ La ilaha illallah, sehingga Jumlahan digit bilangan $=3+3+3+3+3$ $+3+1+0+0=19$

Dalam Tinjauan Nilai Numerik

\begin{tabular}{|l|}
\hline \multicolumn{2}{|c|}{ Teorema 1 } \\
\hline $\begin{array}{l}\text { Jumlahan digit dari nilai numerik kata"Waahid" sesuai } \\
\text { dengan artinya yaitu } 1\end{array}$ \\
\hline
\end{tabular}

Bukti : Kata "Waahid" tersusun dari huruf Wau, Alif, Ha', dan Dal. Dimana nilai numerik dari $W a u=6$, Alif $=1$, $\mathrm{Ha}$ ' $=8$, dan Dal $=4$. Maka nilai numerik dari kata "Waahid" adalah 19. Sehingga jumlah digit dari nilai numerik dari kata "Waahid"adalah $1+9=10$. Jika nilai ini dijumlahkan lagi maka diperoleh $1+0=1$. Sesuai arti dari "waahid" yaitu tunggal atau satu.

Dalam Tinjauan Matematika

\section{Teorema 1}

Bilangan 19 merupakan salah satu bilangan ganjil sekaligus bilangan prima yang memiliki banyak keunikan, diantaranya:

1. Dapat dinyatakan sebagai jumlah pangkat 1 dari 10 dan 9

2. Dapat dinyatakan sebagai selisih pangkat 2 dari 10 dan 9

3. Dapat dinyatakan sebagai jumlahan dari deret angka hasil pangkat 3 dari 10 dan 9

4. Dapat dinyatakan sebagai jumlahan dari deret angka hasil pangkat 4 dari 10 dan 9

5. Angka 19 tersusun dari angka 1 dan angka 9 yang juga memiliki banyak keistimewaan

Pembuktian teorema di atas diserahkan kepada pembaca untuk menunjukkannya.

2. Mengembangkan konsep dasar matematika dari A/Qur'an

1) Himpunan

Himpunan adalah sekumpulan objek yang berbeda yang mempunyai syarat tertentu dan jelas. Dimana objek yang 
dimaksud dapat berupa bilangan, manusia, hewan, tumbuhan, negara, dan sebagainya. Objek ini selanjutnya dinamakan anggota atau elemen dari himpunan itu. Berikut dipaparkan beberapa konsep himpunan dalam Al-Qur'an :

Konsep Himpunan dalam Al-Qur'an
(a) kelompok yang diberi nikmat oleh Allah swt, (b) kelompok yang dilaknat, (c) kelompok yang sesat.

2. Pada surah Al-Baqarah ada 3 golongan manusia, yaitu : (a) golongan orang beriman, (b) golongan orang kafir, (c) golongan orang munafik.

3. Pada surah Al-Waqi'ah, pada hari kiamat manusia dikelompokkan dalam 3 kelompok, yaitu : (a) kelompok terdahulu (assabiqunal awwalun), (b) kelompok kanan, (c) kelompok kiri.

4. Pada surah al-Faathir ayat 1 menjelaskan tentang sekelompok malaikat yang beranggotakan malaikat yang memiliki 2 sayap, 3 sayap, atau 4 sayap bahkan lebih sesuai kehendak Allah swt.

5. Pada surah An-Nuur ayat 45 menjelaskan sekelompok hewan yang beranggotakan hewan yang berjalan tanpa kaki, dengan 2 kaki, 4 atau bahkan lebih sesuai kehendak Allah swt.

\section{2) Bilangan}

Dalam Al-Qur'an disebutkan sebanyak 38 bilangan berbeda. 30 bilangan merupakan bilangan asli dan 8 bilangan merupakan bilangan pecahan (rasional) dan 30 bilangan asli. Berikut dipaparkan konsep bilangan dalam AlQur'an :

Salah Satu Konsep Relasi Bilangan dalam Al-Qur'an

Pada surah Ash-Shaffaat (37) ayat 147 menjelaskan bahwa nabi Yunus diutus kepada umat yang jumlahnya 100000 orang atau lebih. Secara matematika, jika umat nabi Yunus sebanyak $x$ orang, maka $x$ sama dengan 100000 atau $x$ lebih dari 100000. Dalam bahasa matematika, dapat ditulis dengan $x=100000$ atau $x>100000$. Secara ringkas ditulis menjadi $x \geq 100000$.

\section{Konsep Operasi Bilangan dalam Al-Qur'an}

1. Pada surah Al Kahfi (18) ayat 25 berbicara operasi penjumlahan yaitu "...Tiga ratus tahun dan ditambah sembilan tahun (lagi)" 
2. Pada surah Al Ankabut (29) ayat 14 berbicara operasi pengurangan yaitu "...seribu tahun kurang lima puluh tahun."

3. Konsep penjumlahan berulang (perkalian) pada surah AlBaqarah (2) ayat 261. Akan tetapi Al An'am (6) ayat 160 bukan membicarakan operasi bilangan karena amal bukan bilangan

4. Konsep pembagian dalam Al-Qur'an banyak dijumpai pada permasalahan warisan (faraaidh)

3) Perbandingan, Fungsi, dan Persamaan Garis

Berikut dipaparkan konsep perbandingan, fungsi, dan persamaan garis dalam Al-Qur'an yaitu:

\begin{tabular}{|l|}
\hline Konsep Perbandingan dalam Al-Qur'an \\
\hline 1. Pada surah Al-Anfaal ayat 65 bahwa “...Jika ada dua \\
puluh orang yang sabar diantara kamu, niscaya mereka \\
akan dapat mengalahkan dua ratus orang musuh. Dan \\
jika ada seratus orang yang sabar di antara kamu, \\
niscaya mereka akan dapat mengalahkan seribu daripada \\
orang kafir..." Hal ini dapat dituliskan secara matematis : \\
20 orang sabar dalam pasukan mukmin \\
jumlah pasukan mukmin $(\boldsymbol{x})$
\end{tabular}

Pada dua ayat pada surah Al-Anfaal di atas dikatakan perbandingan senilai dimana jika pada surah Al-Anfaal ayat 65 dikonstruksikan daftar sebagai berikut :

\begin{tabular}{|c|c|c|}
\hline $\begin{array}{c}\text { Banyak orang Mukmin } \\
\text { yang Sabar }\end{array}$ & $\begin{array}{c}\text { Banyak orang } \\
\text { kafir }\end{array}$ \\
\hline
\end{tabular}




\begin{tabular}{|r|r|c|}
\hline 20 & $\longleftrightarrow$ & 200 \\
\hline 100 & $\longleftrightarrow$ & 1000 \\
\hline $\begin{array}{r}200 \\
200\end{array}=\frac{100}{1000}=\frac{1}{10}$ atau $1: 10$ artinya 1 orang mukmin \\
yang sabar dapat mengalahkan 10 orang kafir
\end{tabular}

Dan jika pada surah Al-Anfaal ayat 66 dikonstruksikan daftar sebagai berikut :

\begin{tabular}{|r|c|c|}
\hline $\begin{array}{c}\text { Banyak orang Mukmin } \\
\text { yang Sabar }\end{array}$ & $\longleftrightarrow \begin{array}{c}\text { Banyak orang } \\
\text { kafir }\end{array}$ \\
\hline 100 & $\longleftrightarrow$ & 200 \\
\hline 1000 & $\longleftrightarrow$ & 2000 \\
\hline$\frac{100}{200}=\frac{1000}{2000}=\frac{1}{2}$ atau $1: 2$ artinya 1 orang mukmin \\
yang sabar dapat mengalahkan 2 orang kafir \\
\hline
\end{tabular}

Konsep Fungsi dan Persamaan Garis dalam Al-Qur'an Jika pada surah Al-Anfaal ayat 65 menegaskan 1: 10 artinya 1 orang mukmin yang sabar dapat mengalahkan 10 orang kafir. Berapa banyaknya orang mukmin yang dibutuhkan untuk mengalahkan 2000 orang kafir dan sebagainya ? Perhatikan bahwa

$$
\frac{x}{y}=\frac{1}{10} \leftrightarrow \frac{x}{2000}=\frac{1}{10} \leftrightarrow x=\frac{2000}{10}=200
$$

Jadi untuk mengalahkan 2000 orang kafir dibutuhkan 200 kaun Sehingga diperoleh model fungsi di atas yaitu :

$$
x=\frac{1}{10} y \text { atau } y=10 x
$$

Persamaan $x=\frac{1}{10} y$ dapat dinyatakan sebagai fungsi $\mathrm{y}$ ditulis : $f(y)=\frac{1}{10} y$. Bentuk persamaan ini merupakan persamaan garis lurus. Bentuk persamaan $y=10 x$ dapat dinyatakan sebagai fungsi $\mathrm{x}$ ditulis : $f(x)=10 x$. Bentuk persamaan ini juga merupakan persamaan garis lurus

4) Estimasi (taksiran)

Berikut dipaparkan salah satu konsep estimasi dalam Al-Qur'an yaitu:

$$
\text { Salah Satu Konsep Estimasi dalam Al-Qur'an }
$$

Pada surah Ash-Shaffaat (37) ayat 174 bahwa "Dan Kami utus dia kepada seratus ribu orang atau lebih"

\section{Penutup}

Istilah "matematika" lebih tepat digunakan daripada "ilmu pasti" dikarenakan dengan menguasai matematika orang 
akan belajar mengatur jalan pikirannya dan sekaligus belajar menambah kepandaiannya. Dalam memahami matematika dalam Al Qur'an sebaiknya memperhatikan bahwa Al Qur'an merupakan kitab yang memberikan petunjuk bagi orangorang yang beriman yang mengandung sebagian besar tentang ajaran tauhid, syari'ah dan akhlak. Jika dilakukan pengkajian lebih dalam isi maupun kandungan Al-Qur'an terdapat begitu banyak isyarat matematika yang kebenarannya telah dibuktikan oleh matematikawan baik muslim maupun non muslim. Hal inilah yang menunjukkan bahwa yang menjadi mu'jizat nabi Muhammad SAW ini benar-benar merupakan wahyu Allah SWT yang didalam mengandung kebenaran untuk selalu berada pada jalan yang lurus.

Sebagai firman Allah SWT, AI-Qur'an merupakan rujukan utama bagi segala rujukan, sumber dari segala sumber, basis bagi segala ilmu pengetahuan yang di dalamnya diperoleh berbagai informasi baik ilmu maupun solusi atas beragam permasalahan kehidupan yang tidak mengandung pertentangan sebagaimana yang disebutkan dalam firman Allah SWT dalam Q.S. An-Nisa/4 : 82.

Menurut Herry Sukarman pada The World Book Encyclopedia menyebutkan bahwa matematika merupakan salah satu cabang ilmu pengetahuan manusia yang sangat bermanfaat bagi kehidupan. Peranan matematika dalam kehidupan telah Allah SWT paparkan secara jelas dan mendetail dalam 114 surah atau 30 juz, dimana masalah matematika yang paling erat berkaitan dengan masalah faraidh (pembagian harta warisan). Dalam permasalahan faraidh diperlukan pemahaman matematika khususnya pecahan $\frac{2}{3}, \frac{1}{2}, \frac{1}{3}, \frac{1}{4}, \frac{1}{6}$, dan $\frac{1}{8}$.

Selain masalah faraidh yang menunjukkan adanya matematika dalam Al-Qur'an juga terdapat banyak rahasia angka matematika seperti angka 19 yang menunjukkan banyak rahasia matematika dalam kodefikasi penyusunan al-Qur'an dan keseimbangan matematika dalam Al-Qur'an yang banyak ditelaah oleh para ahli tafsir maupun pakar yang tertarik dengan matematika. Salah satu metode untuk menguji keseimbangan Al-qur'an adalah dengan menggunakan metode Parity Check yaitu suatu metode pengelompokan berdasarkan surah homogen dan heterogen yang pertama kali dipublikasikan oleh Prof. Abdullah 
Jalghoom dari Yordania dalam bukunya "The Secrets of the Order of the Qur'an : A Ceontemporary Reading".

\section{Daftar Pustaka}

Abdusysyakir, Ada Matematika Dalam Al-Qur'an. Malang : UIN Malang Press, 2006.

Basya, F. Matematika Islam. Jakarta : Republika, 2004.

Departemen Agama RI, Al-Quran Terjemah Per-Kata. Bandung :Syaamil International, 2007.

Halim, M.A. "Understanding Qur'an : Themes and Style," diterjemahkan oleh Rofik Suhud dengan Judul Memahami Al-Qur'an: Pendekatan Gaya dan Tema, Bandung : Marja', 2002.

Hidayat, M.T. Science Spirituality \& Quran. Yogyakarta : Quantum Sinergis Media, 2011.

http://pustaka.abatasa.co.id/pustaka/detail/tauhid//788/isikan dungan-al-quran.html\#. Diakses tanggal 24 November 2012.

http://www.myquran.org/forum/index.php?topic=752650.

Diakses tanggal 24 November 2012.

Nasution, A.H. Landasan Matematika. Jakarta: Bhratara Karya Aksara, 1987.

Nursupiamin, "Konsep Ortogonalitas dalam Al-Qur'an", AlKhwarizmi, Prodi Pendidikan Matematika Fakultas Tarbiyah STAIN Palopo, Vol.2 Oktober 2013.

--.--.-. Pengantar Dasar Matematika. Makassar : MEMBUMI publishing, 2010.

Rahman, A. Al-Qur'an Sumber Ilmu Pengetahuan. Jakarta : Rineka Cipta, 2000.

Sampayya, A.S. Keseimbangan Matematika Dalam AlQur'an. Jakarta : Republika, 2007.

Sari, W.K. Representasi Digraph untuk Nomor Surat dan banyak Ayat Al-Qur'an (Skripsi), UIN Malang, 2010.

Setyaki, A.A. Aritmatika Jari Metode AHA. Jakarta : Khalifa, 2008.

Sukarman, H. Psikologi Pembelajaran Matematika di SMU (Diklat Matematika untuk Guru Inti MGMP SMU). Yogyakarta: Departemen Pendidikan Nasional, 2002. 